\title{
PERANCANGAN SISTEM PENDUKUNG KEPUTUSAN PENILAIAN PRESTASI PEGAWAI MENGGUNAKAN METODE SAW, AHP, DAN TOPSIS
}

\author{
Ase Suryana ${ }^{1}$, Erwin Yulianto ${ }^{2}$, Khrisna Dea Pratama ${ }^{3}$ \\ Universitas Widyatama ${ }^{1}$, Universitas Langlangbuana ${ }^{2}$ \\ Jl. Cikutra No. 204, Bandung, Jawa Barat ${ }^{1}$, Jl. Karapitan No. 116, Bandung, Jawa Barat ${ }^{2}$ \\ asesuryana@gmail.com ${ }^{1}$,rwinyulianto@yahoo.com² ${ }^{2}$,khrisnadeapratamajtk04@ gmail.com³
}

\begin{abstract}
Abstrak
Pemilihan pegawai terbaik merupakan salah satu aspek yang cukup penting di perusahaan karena dengan sumber daya manusia yang unggul dan memiliki kompetensi tinggi dapat meningkatkan produktivitas dan kinerja suatu perusahaan serta menghasilkan pemimpin-pemimpin hebat di masa depan. Beberapa permasalahan yang terjadi pada pemilihan pegawai terbaik di PT BPD Jawa Barat \& Banten, Tbk (Call Name : bank bjb) antara lain yaitu pengolahan data kandidat pegawai terbaik yang akan diseleksi masih membutuhkan waktu yang lama karena belum memiliki standar dan masih memakai sistem manual sehingga proses penilaian masih belum transparan, akurat dan terpercaya. Penentuan pegawai terbaik di bank bjb sangat memerlukan sistem pendukung keputusan sebagai rekomendasi kepada Direksi. Sistem pendukung keputusan penentuan pegawai terbaik yang dilakukan pada penelitian ini menggunakan tiga metode yaitu Simple Additive Weighting (SAW), Analytical Hierarchy Process (AHP), dan Technique For Order Preference By Similarity To Ideal Solution (TOPSIS). Penelitian akan menghasilkan sebuah sistem pendukung keputusan yang dapat merekomendasikan pegawai terbaik pada bank bjb berdasarkan kriteria yang telah ditetapkan yaitu nilai kinerja individu, nilai kinerja unit kerja, kehadiran, perilaku, pencapaian target kerja, masa kerja, pendidikan, penilaian makalah, presentasi, dan hasil wawancara.
\end{abstract}

Kata Kunci : Sistem Pendukung Keputusan, Pegawai Terbaik, SAW, AHP, TOPSIS

\begin{abstract}
Best employees selection is one aspect which is quite important in the company because of the superior human resources and high competence can improve the productivity and performance of a company and produce great leaders in the future. Some of the problems occurred for best employees selection in PT BPD Jawa Barat and Banten Tbk (Call Name: bank bjb) are best employees candidate data processing who would be selected still take a long time because it has no standards and still use manual system so that the assessment process is still not transparent, accurate and reliable. Determining the best employees in the bank bjb need the decision support systems as a recommendation to the Board of Directors. Decision support system to determining the best employees who performed in this research using three methods : Simple Additive Weighting (SAW), Analytical Hierarchy Process (AHP), and Technique For Order Preference By Similarity To Ideal Solution (TOPSIS). The research will create a decision support system that can recommend the best employees in bank bjb based on predetermined criteria such as individual performance score, work unit performance, attendance, behavior, employment target achievement, employee education, assessment papers, presentations, and interviews results.
\end{abstract}

Keywords : Decision Support System, Best Employee, SAW, AHP, TOPSIS

\section{Pendahuluan}

Setiap perusahaan memerlukan sebuah sistem penilaian kinerja untuk menentukan kinerja dari para pegawainya dari sisi kualitas dan tanggung jawab atas 
pekerjaannya. Jangka waktu pelaksanaan pengukuran kinerja pegawai berbeda-beda, misalnya setiap bulan, setiap tiga bulan ataupun setiap tahun. Komponen Penilaiannya pun berbeda-beda, seperti hasil kinerja, kehadiran, tanggung jawab, komunikasi, pencapaian target, dan lain-lain.

PT BPD Jawa Barat \& Banten, Tbk dengan call name bank bjb merupakan perusahaan daerah dengan fokus bisnis utama yaitu layanan perbankan. bank bjb diklaim sebagai bank daerah terbesar di Indonesia dengan jumlah pegawai yang relatif banyak dibandingkan dengan bank daerah lainnya yaitu berjumlah 7.330 pegawai dan memiliki laba per posisi tahun 2015 yaitu sebesar kurang lebih satu koma empat triliun rupiah.

Seleksi pemilihan pegawai terbaik di bank bjb dilaksanakan dalam beberapa tahap yaitu kinerja individu dan kinerja unit kerja pegawai selama dua tahun terakhir, kehadiran, perilaku, pencapaian target, masa kerja, pendidikan, penilaian makalah, presentasi, dan hasil wawancara secara mandiri. Pegawai yang memiliki kriteria sesuai dengan yang telah ditetapkan akan menerima penghargaan sebagai pegawai terbaik secara periodik. Pegawai terbaik adalah pegawai yang menampilkan perilaku yang sejalan dengan visi, misi, tujuan, budaya dan nilai-nilai perusahaan tersebut

Berdasarkan fakta di lapangan, kendala yang ditemukan dalam proses penentuan pegawai terbaik di bank bjb yaitu sebagai berikut :

1. Pengolahan data kandidat pegawai yang akan diseleksi membutuhkan waktu yang lama.

2. Penentuan pegawai terbaik di bank bjb belum memiliki standar / metode yang baku, karena masih memakai sistem manual dalam setiap proses penilaiannya.

3. Rekomendasi pegawai yang disampaikan oleh pemimpin unit kerja masih terbilang subjektif, tidak sejalan dengan penilaian kinerja pegawainya.

4. Proses penilaian oleh tim masih belum transparan dikarenakan masih terdapat unsur politik.

Salah satu upaya untuk dapat mengolah data-data penilaian lebih objektif maka perlu dibangun Sistem Pendukung Keputusan yang dapat memberikan rekomendasi pegawai yang berhak mendapat penghargaan dari berbagai kriteria penilaian yang telah ditentukan oleh bank bjb.

\section{KAJIAN PUSTAKa}

\section{II.1 Sistem Pendukung Keputusan}

Beberapa definisi Sistem Pendukung Keputusan menurut para ahli diantaranya :

1. Sistem pendukung keputusan adalah sebuah sistem yang mampu memberikan kemampuan pemecahan masalah maupun kemampuan pengkomunikasian untuk masalah dengan kondisi semi terstruktur dan tak terstruktur. (Turban, 2005)

2. Sistem pendukung keputusan merupakan sistem informasi yang menyediakan informasi, pemodelan dan pemanipulasian data yang mampu untuk mendukung analisis data secara ad hoc dan pemodelan keputusan serta berorientasi pada perencanaan masa depan. (Kusrini, 2007)

3. Sistem pendukung keputusan adalah suatu sistem informasi berbasis komputer yang melakukan pendekatan untuk menghasilkan berbagai alternatif keputusan untuk membantu pihak tertentu dalam menangani permasalahan dengan menggunakan data dan model. (Daihani, 2001)

Menurut Turban (2005:30), sistem pendukung keputusan terdiri dari tiga komponen utama atau sub sistem, yaitu:

1. Sub sistem data (database), merupakan komponen sistem pendukung keputusan penyedia data bagi sistem. Data yang dimaksud disimpan dalam suatu pangkalan data (database) yang diorganisasikan oleh suatu sistem yang disebut dengan Data Base Management System (DBMS). Pangkalan data dalam sistem pendukung keputusan berasal dari dua sumber yaitu sumber internal (dari dalam perusahaan) dan sumber eksternal (dari luar perusahaan). Data eksternal ini sangat berguna bagi manajemen dalam mengambil keputusan.

2. Sub sistem model (model base), merupakan kemampuan sistem pendukung keputusan dalam mengintegrasikan data dengan modelmodel keputusan. Model merupakan suatu peniruan dari alam nyata. Sistem pangkalan model harus tetap dijaga flexibilitasnya, artinya harus ada fasilitas yang mampu membantu pengguna untuk memodifikasi atau menyempurnakan model seiring dengan 
perkembangan pengetahuan. Hal lain yang perlu diperhatikan adalah pada setiap model yang disimpan hendaknya ditambahkan rincian keterangan dan penjelasan yang kompeherensif mengenai model yang dibuat.

3. Sub sistem dialog (user system interface), fasilitas yang mampu mengintegrasikan sistem pendukung keputusan yang terpasang dengan pengguna secara interaktif. Sistem diartikulasikan dan diimplementasikan sehingga pengguna atau pemakai dapat berkomunikasi dengan sistem yang dirancang. Fasilitas yang dimiliki oleh sub sistem ini antara lain bahasa aksi (action language), bahasa tampilan, dan bahasa pengetahuan.

Dari ketiga sub komponen sistem pendukung keputusan di atas, dapat digambarkan secara keseluruhan seperti pada gambar 1 berikut.

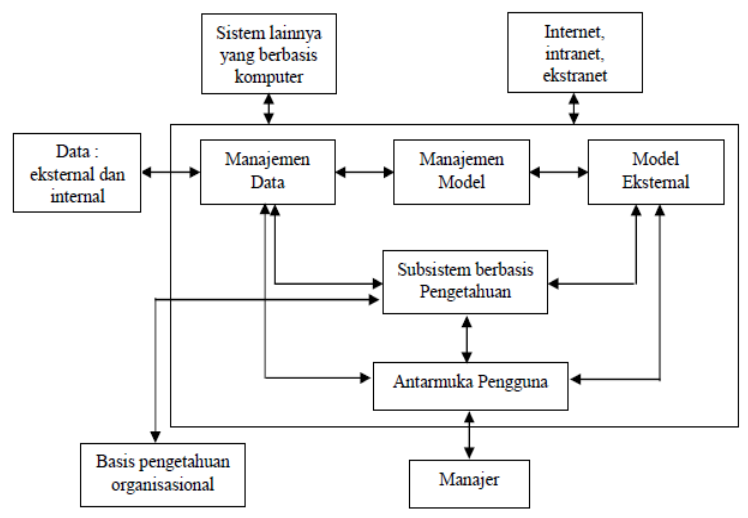

Gambar 1. Komponen Sistem Pendukung Keputusan

\section{II.2 Metode Simple Additive Weighting (SAW)}

Metode SAW dikenal dengan istilah metode penjumlahan terbobot. Konsep dasar metode SAW adalah mencari penjumlahan terbobot dari rating kinerja pada setiap alternatif dan semua atribut. (Kusumadewi, 2006:74) Metode SAW membutuhkan proses normalisasi matriks keputusan ke suatu skala yang dapat diperbandingkan dengan semua rating alternatif yang ada. Metode SAW dipilih karena mampu menyeleksi alternatif terbaik dari sejumlah alternatif berdasarkan kriteria-kriteria yang ditentukan. Kriteria-kriteria tersebut bersifat dinamis dan nilai setiap bobot kriteria dapat diubah sesuai keinginan pengguna.
Proses normalisasi matriks

keputusan menggunakan runus 1 sebagai berikut :

$$
r i j=\left\{\begin{array}{c}
\frac{X i j}{\text { Max } i \text { Xij }} j i k a \text { j adalah atribut keuntungan (benefit) } \\
\quad \frac{\text { Min } i \text { Xij }}{X i j} \text { jika } j \text { adalah atribut biaya (cost) }
\end{array}\right.
$$

Rumus 1. Normalisasi Matriks Keputusan

Dimana $r_{i j}$ adalah rating kinerja ternormalisasi dari alternatif $A_{i}$ pada atribut $C_{j} ; i=1,2, \ldots, m$ dan $j=$ $1,2, \ldots$. N Nilai preferensi untuk setiap alternatif $\left(\mathrm{C}_{\mathrm{i}}\right)$ diberikan dengan rumus 2 berikut :

$$
V i=\sum_{j=1}^{n} W j r i j
$$

Rumus 2. Nilai Preferensi Untuk Setiap Alternatif

Nilai $V_{i}$ yang lebih besar mengindikasikan bahwa alternatif $A_{\mathrm{i}}$ lebih terpilih.

\section{II.3 Metode Analitycal Hierarchy Process (AHP)}

Metode AHP dikembangkan oleh Prof. Thomas Lorie Saaty dari Wharton Busines School di awal tahun 1970 yang digunakan untuk mencari ranking atau urutan prioritas dari berbagai alternatif dalam pemecahan suatu permasalahan. [Sinaga, 2009] Metode AHP merupakan metode pengambilan keputusan multi kriteria dalam masalah yang kompleks. Metode ini mengkombinasikan faktorfaktor kualitatif dan kuantitatif untuk menentukan prioritas.

Langkah-langkah dalam metode AHP sebagai berikut (Kusrini, 2007):

1. Mendefinisikan masalah dan menentukan solusi yang diinginkan, lalu menyusun hirarki dari permasalahan yang dihadapi.

2. Menentukan prioritas elemen dengan membuat perbandingan pasangan yaitu membandingkan elemen secara berpasangan sesuai kriteria yang diberikan.

3. Sintesis, pertimbangan-pertimbangan terhadap perbandingan berpasangan disintesis untuk memperoleh keseluruhan prioritas.

4. Mengukur Konsistensi, untuk mengetahui seberapa baik konsistensi yang ada karena pemutus tidak menginginkan keputusan berdasarkan peritmbangan dengan konsistensi 
yang rendah. Hal-hal yang dilakukan dalam langkah ini adalah sebagai berikut :

a. Kalikan setiap nilai pada kolom pertama dengan prioritas relatif elemen pertama, nilai pada kolom kedua dengan prioritas relatif elemen kedua dan seterusnya.

b. Jumlahkan setiap baris.

c. Hasil Dari penjumlahan baris dibagi dengan elemen prioritas relatif yang bersangkutan.

d. Jumlahkan hasil bagi diatas dengan banyaknya elemen yang ada, hasilnya disebut $\lambda$ maks.

e. Hitung Consistency Index (CI) dengan rumus 3 di bawah ini :

$$
\begin{aligned}
& C l=\frac{(\lambda \text { maks }-\mathrm{n})}{(n-1)} \\
& \text { dimana } \mathrm{n}=\text { banyaknya elemen }
\end{aligned}
$$

Rumus 3. Consistency Index (CI)

f. Hitung Rasio Konsistensi / Consistency Ratio (CR) dengan rumus 4.

$$
\begin{aligned}
& C R=\frac{C l}{I R} \\
& \text { dimana : } \\
& \mathrm{CR}=\text { Consistency Ratio } \\
& \mathrm{CI}=\text { Consistency Index } \\
& \mathrm{IR}=\text { Index Random Consistency }
\end{aligned}
$$

Rumus 4. Consistency Ratio (CR)

g. Memeriksa konsistensi hirarki. Jika nilainya lebih dari $100 \%$ maka penilaian data judgemenet harus diperbaiki. Namun jika rasio konsistensi (CI/IR) kurang atau sama dengan 0,1 maka hasil perhitungan bisa dinyatakan benar. Daftar Indeks Random Konsistensi (IR) bisa dilihat dalam tabel 1.

\section{II.4 Metode Technique For Others Reference by Similarity to Ideal Solution (TOPSIS)}

TOPSIS adalah salah satu metode pengambilan keputusan multikriteria yang pertama kali diperkenalkan oleh Yoon dan Hwang (1981). TOPSIS menggunakan prinsip bahwa alternatif yang terpilih harus mempunyai jarak terdekat dari solusi ideal positif dan terjauh dari solusi ideal negatif dari sudut pandang geometris dengan menggunakan jarak euclidean untuk menentukan kedekatan relatif dari suatu alternatif dengan solusi optimal.
Langkah-langkah dalam menyelesaikan sebuah kasus dengan Metode TOPSIS yaitu [Kusumadewi, 2006] :

1. Membuat matriks keputusan yang ternormalisasi

2. Menentukan matriks solusi ideal positif \& matriks solusi ideal negatif.

3. Menentukan jarak antara nilai setiap alternatif dengan matriks solusi ideal positif \& matriks solusi ideal negatif.

4. Menentukan nilai preferensi untuk setiap alternatif.

5. Mencari rating kinerja setiap alternatif Ai pada setiap kriteria $\mathrm{Cj}$ yang ternormalisasi dengan rumus 5 sebagai berikut :

$$
r i j=\frac{X i j}{\sqrt{\sum_{i=1}^{m} x_{U}^{2}}}
$$

dimana :

$\mathrm{i}=1,2,3, \ldots . \mathrm{m}$

$\mathrm{j}=1,2,3, \ldots . \mathrm{n}$

Rumus 5. Rating Kinerja Setiap Alternatif

6. Solusi ideal positif $A+$ dan solusi ideal negatif A- dapat ditentukan berdasarkan rating bobot ternormalisasi (yij) dengan rumus 6 berikut.

$$
\begin{aligned}
& \text { y } i j=\text { w } i \text { r } i j \\
& A^{+}=\left(y_{1}^{+}, y_{2}{ }^{+}, \ldots, y_{n}{ }^{+}\right) \\
& A^{-}=\left(y=-, y_{2}^{-}, \ldots ., y_{n}{ }^{-}\right)
\end{aligned}
$$

Dengan :

$$
\begin{aligned}
Y_{j}^{+} & =\left\{\begin{array}{l}
\max _{i} Y i j ; j i k a j \text { adalah atribut keuntungan } \\
\min _{i} Y i j ; j i k a j \text { adalah atribut biaya }
\end{array}\right. \\
Y_{j}^{-} & =\left\{\begin{array}{l}
\min _{i} Y i j ; j i k a \text { jadalah atribut keuntungan } \\
\max _{i} Y i j ; j i k a j \text { adalah atribut biaya }
\end{array}\right.
\end{aligned}
$$

Rumus 6. Rating Bobot Ternormalisasi

7. Jarak antara alternatif $A_{i}$ dengan solusi ideal positif dirumuskan dengan formula 7 berikut :

$$
\begin{aligned}
D_{i}^{+} & =\sqrt{\sum_{j=1}^{n}\left(y_{i}^{+}-y_{i j}\right)^{2}} ; i=1,2, \ldots, m \\
D_{i}^{-} & =\sqrt{\sum_{j=1}^{n}\left(y_{i j}-y_{i}^{-}\right)^{2}} ; i=1,2, \ldots, m \\
& \quad \text { Rumus 7. Jarak Antara Alternatif }
\end{aligned}
$$

8. Nilai preferensi untuk setiap alternatif $\left(\mathrm{V}_{\mathrm{i}}\right)$ diberikan rumus 8 sebagai berikut :

$V_{i}=\frac{D_{i}^{-}}{D_{i}^{-}+D_{i}^{+}} ; i=1,2, \ldots, m$

Rumus 8. Nilai Preferensi Untuk Setiap Alternatif

Penggunaan ketiga metode dalam perhitungan untuk seleksi pegawai terbaik ini dapat menghasilkan 
keluaran yang lebih rinci dan valid, dikarenakan setiap metode memiliki pendekatan yang berbeda.Seperti halnya pada metode SAW, dilakukan penilaian bobot preferensi dari sepuluh kriteria (C), yaitu Nilai Kinerja Individu, Nilai Kinerja Unit Kerja, Kehadiran, Perilaku, Pencapaian Target Kerja, Masa Kerja, Pendidikan, Nilai Makalah, Nilai Presentasi, dan Nilai Wawancara, untuk kemudian dilakukan penjumlahan terbobot dari rating kinerja dalam hal ini pegawai pada setiap alternatif untuk semua atribut tersebut. Setiap metode akan melakukan perhitungan kinerja dari setiap pegawai berdasarkan kriteria dan bobot sesuai mekanisme perhitungan untuk masingmasing metode. Dari ketiga metode tersebut, akan ditemukan hasil perhitungan yang telah terakumulasi. Hasil akhir dari akumulasi tersebut akan di urutkan berdasarkan total akumulasi yang tertinggi atas dasar hasil akhir dari setiap metode tersebut.

\section{METODE PENELITIAN}

\section{Listen To Customer}

Pada tahap listen to customer, kegiatan penelitian dibagi menjadi 2 fase yaitu :

a. Persiapan Penelitian

Pada tahap ini pengembang mendengar kebutuhan user dengan menggunakan teknik wawancara dalam mengumpulkan data. Data yang menjadi focus utama dalam penelitian ini yaitu bagaimana menetapkan kriteriakriteria yang akan diproses dalam sistem pendukung keputusan. Selain itu, bobot setiap kriteria pun harus ditetapkan dalam kebutuhan user karena itu salah satu faktor dalam perhitungan sistem pendukung keputusan yang nantinya akan menghasilkan daftar pegawai terbaik di bank bjb.

b. Analisis

Pada tahap ini dilakukan identifikasi proses penentuan pegawai terbaik di bank bjb berdasarkan hasil pengumpulan data. Dalam penelitian ini data yang dibutuhkan dibagi menjadi dua, yaitu :

i. Data Utama berupa data penilaian kinerja seluruh pegawai selama 2 tahun terakhir.

ii. Data pendukung berupa data unit kerja bank bjb, data masa kerja pegawai, data pendidikan, data kepangkatan, data jabatan, data absensi pegawai, data kompetensi pegawai, data perilaku, dan data pencapaian target kerja yang dikumpulkan dari beberapa sumber.

\section{Build / Revise Mock Up}

Tahap ini merupakan desain sistem / rancangan model dan alur pembangunan sistem penentuan pegawai terbaik di bank bjb sesuai dengan analisis yang telah dilakukan sebelumnya. Perancangan sistem yang dibuat meliputi perancangan use case diagram, class diagram, database design dan sitemap design.

\section{Customer Test Drives Mock-Up}

Setelah tahap build / revise mock-up selesai, maka tahap terakhir yaitu customer test drives mockup / pengujian prototype serta hasil keputusan dari pengujian. Tahap ini merupakan tahap utama dari sistem yang dibuat karena perhitungan setiap metode SAW, AHP dan TOPSIS dilakukan dan terlihat hasil / daftar urutan pegawai yang dapat direkomendasikan sebagai pegawai terbaik di bank bjb.

\section{Pembahasan}

\section{IV.1 Proses Bisnis}

Berdasarkan hasil tahapan Listen To Customer, proses bisnis penentuan pegawai terbaik dapat dilihat pada gambar 2 berikut.

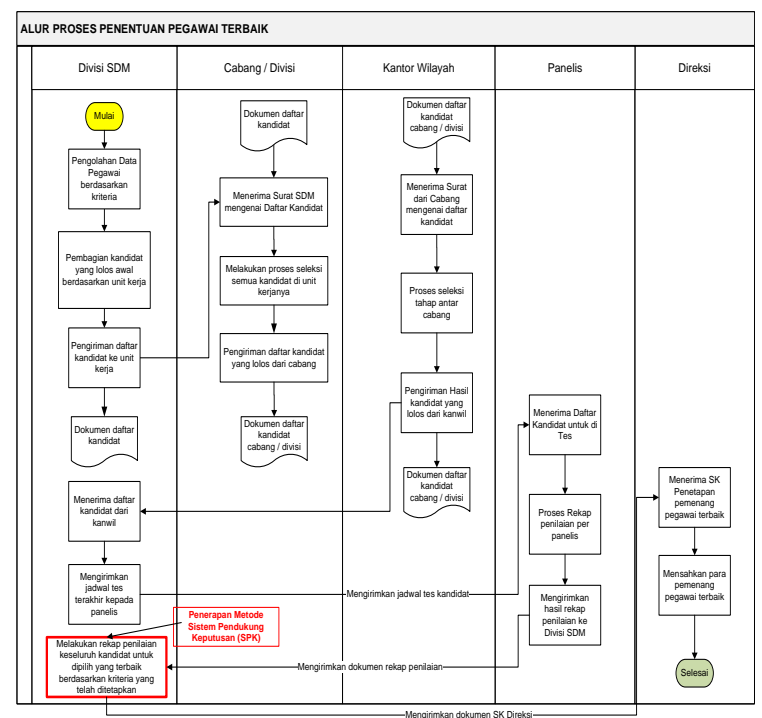

Gambar 2. Alur Proses Penentuan Pegawai Terbaik

Secara singkat proses penentuan pegawai terbaik dimulai dari tingkat cabang. Divisi Sumber Daya Manusia melakukan proses pengolahan data seluruh pegawai berikut data kinerja dan memilih pegawai dengan penilaian sangat baik minimal 5 tahun terakhir. Daftar dikirimkan ke Cabang/Divisi. Cabang/divisi mereview data kinerja dengan 
melibatkan 5 orang reviewer. Hasil penilaian berupa urutan dari nilai tertinggi dan dikategorikan berdasarkan jabatan. Setelah diurutkan, akan dipilih kandidat yang mewakili cabang yang terdiri atas staff, officer dan manager. Wakil dari divisi akan ditambahkan 1 senior manager.

Kantor wilayah akan memilih pemimpin cabang terbaik untuk dikirimkan ke SDM pusat dan melakukan test untuk perwakilan staf dari setiap cabang. Data dari seluruh kanwil dan divisi kemudian akan diolah lebih lanjut oleh SDM dan para karyawan terpilih akan mengikuti test lebih lanjut. Karyawan yang lulus seleksi ini akan diminta untuk mempresentasikan topik tertentu. Presentasi kandidat karyawan terbaik akan diuji oleh panelis, yang kemudian akan melaporkan hasilnya kepada divisi SDM. Divisi SDM akan mengolah hasil akhir untuk kemudian disampaikan kepada Dewan Direksi. Keputusan akhir dan pengumuman penentuan pegawai terbaik akan ditetapkan oleh direksi.

Selama ini, pengolahan data pada proses seleksi tersebut dilakukan secara manual sehingga

\section{IV.2 Penentuan Parameter}

Berdasarkan hasil wawancara dengan pihak bank bjb Divisi SDM, didapat sepuluh parameter kriteria penilaian sebagaimana tabel 2 .

Tabel 2. Kriteria Penilaian

\begin{tabular}{|c|c|c|}
\hline Kode & Kriteria & Definisi \\
\hline$\overline{\mathrm{C} 1}$ & $\begin{array}{l}\text { Nilai Kinerja } \\
\text { Individu }\end{array}$ & $\begin{array}{l}\text { Penilaian rata-rata kinerja individu } \\
\text { pegawai selama } 2 \text { tahun terakhir }\end{array}$ \\
\hline $\mathrm{C} 2$ & $\begin{array}{l}\text { Nilai Kinerja } \\
\text { Unit Kerja }\end{array}$ & $\begin{array}{l}\text { Penilaian rata-rata kinerja unit kerja } \\
\text { berdasarkan dimana pegawai } \\
\text { tersebut ditempatkan }\end{array}$ \\
\hline $\mathrm{C} 3$ & Kehadiran & Prosentase kehadiran pegawai \\
\hline $\mathrm{C} 4$ & Perilaku & $\begin{array}{l}\text { Penilaian perilaku pegawai sehari- } \\
\text { hari, apakah sudah mencerminkan } \\
\text { corporate image dan budaya } \\
\text { perusahaan }\end{array}$ \\
\hline $\mathrm{C} 5$ & $\begin{array}{l}\text { Pencapaian } \\
\text { Target Kerja }\end{array}$ & Prosentase pencapaian target kerja \\
\hline C6 & Masa Kerja & $\begin{array}{l}\text { Lama waktu pegawai tersebut } \\
\text { menjadi pegawai selama di bank bjb }\end{array}$ \\
\hline $\mathrm{C} 7$ & Pendidikan & Tingkat pendidikan pegawai \\
\hline $\mathrm{C} 8$ & $\begin{array}{l}\text { Nilai } \\
\text { Makalah }\end{array}$ & $\begin{array}{l}\text { Nilai makalah saat pegawai } \\
\text { melakukan seleksi pegawai terbaik }\end{array}$ \\
\hline $\mathrm{C} 9$ & $\begin{array}{l}\text { Nilai } \\
\text { Presentasi }\end{array}$ & $\begin{array}{l}\text { Nilai presentasi saat pegawai } \\
\text { memaparkan bahan materi }\end{array}$ \\
\hline $\mathrm{C} 10$ & $\begin{array}{l}\text { Nilai } \\
\text { Wawancara }\end{array}$ & $\begin{array}{l}\text { Nilai wawancara yang dilakukan } \\
\text { oleh panelis }\end{array}$ \\
\hline
\end{tabular}

Dari masing-masing kriteria pada tabel 2 tersebut akan ditentukan bobot-bobotnya yang yang terdiri dari lima bilangan fuzzy yaitu Sangat Tinggi (ST) dengan bobot 100, Tinggi $(\mathrm{T})$ dengan bobot 80 , Sedang (S) dengan bobot 60, Rendah (R) dengan bobot 40, dan Sangat Rendah (SR) dengan bobot 20 .

Setelah menentukan bobot setiap kriteria seperti pada tabel-tabel di atas, tahap selanjutnya adalah membuat bobot preferensi atau tingkat kepentingan dari setiap kriteria yang telah ditetapkan oleh pihak bank bjb, dengan bobot preferensi maksimal sebesar 500 dan mengacu pada informasi variabel pada tabel 2 yang dipetakan terhadap tabel 3 .

Sesuai dengan kesepakatan pada saat wawancara, maka proses penentuan pegawai terbaik akan menggunakan 15 sample dalam proses perhitungan seluruh metode yang akan. Pertimbangan mengambil 15 sample dikarenakan telah mewakili 50\% dari seluruh peserta yang lolos pada tahap akhir saat ini yang berjumlah 30 orang.

Tabel 3. Bobot Preferensi

\begin{tabular}{clc}
\hline \hline Kode & \multicolumn{1}{c}{ Kriteria } & $\begin{array}{c}\text { Bobot } \\
\text { Preferensi }\end{array}$ \\
\hline \hline C1 & Nilai Kinerja Individu & 100 \\
C2 & Nilai Kinerja Unit Kerja & 60 \\
C3 & Kehadiran & 20 \\
C4 & Perilaku & 20 \\
C5 & Pencapaian Target Kerja & 40 \\
C6 & Masa Kerja & 20 \\
C7 & Pendidikan & 20 \\
C8 & Nilai Makalah & 60 \\
C9 & Nilai Presentasi & 80 \\
C10 & Nilai Wawancara & 80 \\
\hline \hline
\end{tabular}

Pengolahan data di atas menggunakan metoda AHP adalah sebagai berikut :

\section{A. Metoda SAW}

Menentukan skor alternative penilaian seperti pada tabel 4.

Selanjutnya dilakukan normalisasi metoda SAW seperti contoh untuk elemen matriks r11 seperti berikut:

$$
\begin{aligned}
& r_{11}=\frac{X_{11}}{\max 1\left|X_{11}\right|} \\
& =\overline{\max [100 ; 20 ; 20 ; 40 ; 80 ; 100 ; 60 ; 20 ; 40 ; 80 ; 80 ; 20 ; 60 ; 100 ; 40 ; 20 ; 60 ; 60 ; 20 ; 20]} \\
& =\frac{100}{100}=1
\end{aligned}
$$


Tabel 4. Penentuan Alternatif Penilaian

\begin{tabular}{ccccccccccc}
\hline \hline & C1 & C2 & C3 & C4 & C5 & C6 & C7 & C8 & C9 & C10 \\
\hline \hline A1 & 100 & 80 & 80 & 80 & 60 & 20 & 40 & 60 & 80 & 80 \\
A2 & 20 & 20 & 100 & 80 & 80 & 20 & 60 & 80 & 100 & 80 \\
A3 & 20 & 20 & 100 & 100 & 60 & 20 & 60 & 60 & 60 & 100 \\
$\cdots$ & $\cdots$ & $\cdots$ & $\cdots$ & & & & & & & \\
$\cdots$ & $\cdots$ & $\cdots$ & $\cdots$ & & & & & & & \\
A15 & 40 & 80 & 80 & 40 & 60 & 20 & 60 & 60 & 80 & 80 \\
Sumber : Divisi SDM bank bjb & & & & & &
\end{tabular}

Sehingga dibentuk matriks normalisasi seperti pada gambar 4.

Selanjutnya akan dihitung skor masing-masing pegawai untuk melakukan perankingan bobot preferensi seperti pada contoh berikut:

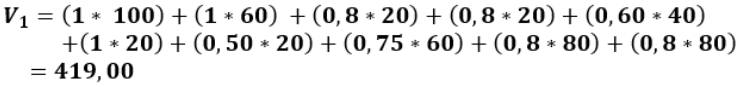

Setelah dihitung semua nilai (V1) untuk setiap pegawai, hasilnya disusun dalam bentuk ranking seperti pada tabel 5 .

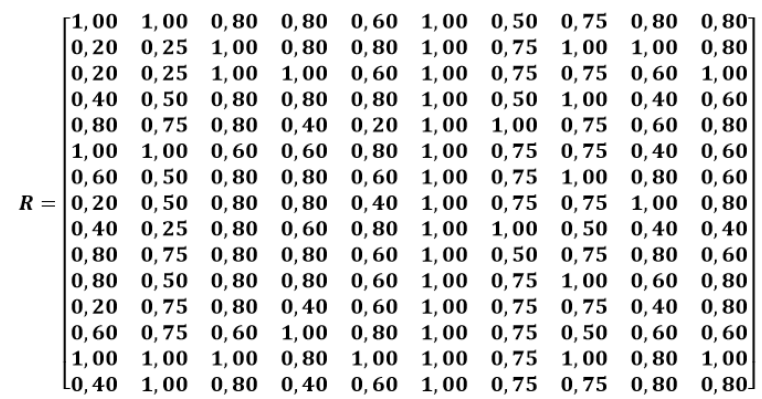

Gambar 4. Matriks Normalisasi

Tabel 5. Ranking Bobot Preferensi

\begin{tabular}{clcc}
\hline \hline NIK & Nama Pegawai & Hasil & Peringkat \\
\hline \hline $13.87 .66 \mathrm{xx}$ & Pegawai-x14 & 475 & 1 \\
$13.88 .62 \mathrm{xx}$ & Pegawai-x6 & 419 & 2 \\
$13.89 .62 \mathrm{xx}$ & Pegawai-x3 & 376 & 3 \\
$\ldots \ldots \ldots \ldots$ & $\ldots \ldots \ldots \ldots \ldots$ & $\ldots \ldots \ldots \ldots$ & $\ldots \ldots \ldots \ldots$ \\
$\ldots \ldots \ldots \ldots$ & $\ldots \ldots \ldots \ldots \ldots$ & $\ldots \ldots \ldots \ldots$ & $\ldots \ldots \ldots \ldots$ \\
$\ldots \ldots \ldots \ldots$. & $\ldots \ldots \ldots \ldots \ldots$ & $\ldots \ldots \ldots \ldots$ & $\ldots \ldots \ldots \ldots$ \\
$13.89 .66 \mathrm{xx}$ & Pegawai-x5 & 249 & 15 \\
\hline \hline
\end{tabular}

\section{B. Metode AHP}

$$
C I=\frac{\lambda \max -n}{n-1}=\frac{10,137-10}{10-1}=0,015
$$

$$
C R=\frac{G I}{R I}=\frac{0,015}{1,49}=0,010<0,100
$$

Karena CR $<0,100$ berarti preferensi atas penetapan pihak Divisi SDM bank bjb adalah konsisten.

Dari hasil perhitungan pada tabel diatas, menunjukkan bahwa kriteria nilai kinerja individu merupakan kriteria paling penting bagi pihak bank bjb dalam penentuan pegawai terbaik di bank bjb dengan bobot 0,291 atau $29,1 \%$.

Selanjutnya untuk memperoleh vektor prioritas, setiap unsur pada tabel disetiap baris dikalikan dan selanjutnya ditarik akar berpangkat $n$. Hasil dari setiap baris kemudian dibagi dengan jumlah dari hasil semua baris, maka matriks vektor prioritas dapat terlihat pada tabel 6 .

Perbandingan berpasangan untuk kriteria nilai kinerja individu pada 15 pegawai yang menjadi sample diperoleh hasil preferensi dari penetapan pihak bank bjb seperti pada tabel 7 .

Tabel 6. Contoh Matriks Vektor Prioritas

\begin{tabular}{ccc}
\hline \hline & $\sum$ pengali & vektor prioritas \\
\hline \hline $\mathrm{C} 1$ & 35,414 & 0,579 \\
$\mathrm{C} 2$ & 2,378 & 0,039 \\
$\ldots \ldots$ & $\ldots \ldots$ & $\ldots \ldots$ \\
$\mathrm{C} 10$ & 10,091 & 0,165 \\
\hline \hline
\end{tabular}

Tabel 7. Contoh Matriks Faktor Evaluasi untuk Kriteria Nilai Kinerja Individu

\begin{tabular}{cccccccc}
\hline \hline & A1 & A2 & A3 & A4 & A5 & $\ldots \ldots$ & A15 \\
\hline \hline A1 & 1 & 8 & 8 & 6 & 2 & $\ldots \ldots$ & 6 \\
A2 & $1 / 8$ & 1 & 1 & $1 / 2$ & $1 / 6$ & $\ldots \ldots$ & $1 / 2$ \\
$\ldots \ldots$ & $\ldots \ldots$ & $\ldots \ldots$ & $\ldots \ldots$ & $\ldots \ldots$ & $\ldots \ldots$ & $\ldots \ldots$ & $\ldots \ldots$ \\
$\ldots \ldots$ & $\ldots \ldots$ & $\ldots \ldots$ & $\ldots \ldots$ & $\ldots \ldots$ & $\ldots \ldots$ & $\ldots \ldots$ & $\ldots \ldots$ \\
$\ldots \ldots$ & $\ldots \ldots$ & $\ldots \ldots$ & $\ldots \ldots$ & $\ldots \ldots$ & $\ldots \ldots$ & $\ldots \ldots$ & $\ldots \ldots$ \\
$\mathrm{A} 14$ & 1 & 8 & 8 & 6 & 2 & 1 & 6 \\
$\mathrm{~A} 15$ & $1 / 6$ & 2 & 2 & 1 & 4 & $1 / 6$ & 1 \\
\hline \hline
\end{tabular}

Dengan unsur-unsur pada tiap kolom dibagi dengan jumlah kolom yang bersangkutan, maka akan diperoleh bobot relatif yang dinormalkan. Nilai vector eigen dihasilkan dari rata-rata bobot relatif untuk setiap baris.

Pada contoh di atas, diperoleh vector eigen untuk baris pertama adalah :

\begin{tabular}{|c|c|c|c|c|c|c|c|c|c|c|c|c|c|c|c|c|}
\hline & A1 & A2 & A3 & A4 & A5 & A6 & Av & AS & A9 & A10 & A11 & Al2 & A13 & A14 & A15 & $\begin{array}{c}\text { veltor } \\
\text { eigen }\end{array}$ \\
\hline A1 & 0,167 & 0,133 & 0,133 & 0,154 & 0,132 & 0,167 & 0,126 & 0,133 & 0,154 & 0,175 & 0,175 & 0,133 & 0,178 & 0,167 & 0,154 & 0,152 \\
\hline
\end{tabular}

Untuk $\mathrm{n}=10, \mathrm{RI}=1,49$ (tabel kusrini), maka: 
Selanjutnya nilai eigen maksimum $\left(\lambda_{\text {maksimum }}\right)$ didapat dengan menjumlahkan hasil jumlah kolom dengan vektor eigen. Nilai eigen maksimum yang dapat diperoleh adalah:

$\lambda_{\text {maksimum }}=(6 \times 0,152)+(60 \times 0,015)+(60 \times 0,015)+(39 \times$ $0,026)+(15,167 \times 0,09)+(6 \times 0,152)+(31,75 \times 0,05)+(60 \times$ $0,015)+(39 \times 0,026)+(11,417 \times 0,09)+(11,417 \times 0,09)+(60 \times$ $0,017)+(22,5 \times 0,056)+(6 \times 0,16)+(39 \times 0,046)$

$$
=16,594
$$

Karena matriks berordo 15 (yakni terdiri dari 15 kriteria), nilai indeks konsistensi yang diperoleh sebagai berikut:

$$
C I=\frac{\lambda \max -n}{n-1}=\frac{16,594-15}{15-1}=0,114
$$

Untuk n $=15, \mathrm{RI}=1,59$ (tabel kusrini), maka:

$C R=\frac{C I}{R I}=\frac{0,114}{1,59}=0,077<0,100$

Karena CR $<0,100$ berarti preferensi atas penetapan dengan pihak Divisi SDM bank bjb adalah konsisten.

Dari hasil perhitungan pada tabel diatas, diperoleh urutan prioritas untuk kriteria nilai kinerja individu yaitu A14 (Pegawai-X14) menjadi prioritas utama dengan nilai bobot 0,160 atau $16 \%$.

Hasil perhitungan di atas kemudian diolah lagi dengan metode TOPSIS. Langkah awal yaitu menyusun matriks keputusan yang ternormalisasi untuk TOPSIS, seperti pada tabel 8.

Tabel 8. Matriks Keputusan Metode Topsis

\begin{tabular}{cccccc}
\hline \hline & $\mathrm{C} 1$ & $\mathrm{C} 2$ & $\mathrm{C} 3$ & & $\mathrm{C} 10$ \\
\hline \hline & & & & & \\
$\mathrm{A} 1$ & 0,4 & 0,37 & 0,25 & $\ldots$. & 0,28 \\
$\mathrm{~A} 2$ & 0,08 & 0,09 & 0,31 & $\ldots \ldots$ & 0,28 \\
$\ldots$. & $\ldots \ldots$ & $\ldots \ldots$ & $\ldots \ldots$ & $\ldots$. & \\
$\mathrm{A} 14$ & 0,4 & 0,37 & 0,31 & $\ldots$. & 0,34 \\
$\mathrm{~A} 15$ & 0,16 & 0,37 & 0,25 & $\ldots \ldots$ & 0,28 \\
\hline \hline
\end{tabular}

Setelah menghitung matriks keputusan normalisasi, selanjutnya adalah menghitung matriks keputusan berbobot sebagai berikut:

$$
\begin{aligned}
& Y_{11}=r_{11} \cdot w_{1}=(0,399)(100)=39,900 \\
& Y_{21}=r_{21} \cdot w_{2}=(0,080)(20)=1,600 \\
& Y_{a 1}=r_{a 1} \cdot w_{a}=(0,080)(20)=1,600
\end{aligned}
$$

Cuplikan matriks keputusan berbobot dapat dilihat pada tabel 9.
Tabel 9. Matriks Keputusan Berbobot

\begin{tabular}{cccccccc}
\hline \hline & $\mathrm{C} 1$ & $\mathrm{C} 2$ & $\mathrm{C} 3$ & $\mathrm{C} 4$ & $\mathrm{C} 5$ & $\ldots$ & $\mathrm{C} 10$ \\
\hline \hline $\mathrm{A} 1$ & 39,9 & 29,4 & 20,1 & 22,2 & 13,7 & $\ldots$ & 22 \\
$\mathrm{~A} 2$ & 1,6 & 1,84 & 31,4 & 22,2 & 24,3 & $\ldots$ & 22 \\
$\ldots \ldots$ & $\ldots \ldots$ & $\ldots \ldots$ & $\ldots \ldots$ & $\ldots \ldots$ & $\ldots \ldots$ & $\ldots$ & $\ldots \ldots$ \\
\hline \hline
\end{tabular}

Untuk menentukan matriks ideal positif diperoleh dari pencarian nilai tertinggi dari nilai matriks berbobot, sedangkan untuk mencari matriks ideal negatif ditentukan dari pencarian nilai terendah dari matriks terbobot. Untuk contoh di atas, nilai tertinggi dan terendah untuk baris pertama adalah : Y1 $\max =$ 39.9, dan Y1min = 1.6.

Perhitungan selanjutnya adalah menentukan separation measure yaitu pengukuran jarak dari suatu alternatif ke solusi ideal positif dan solusi ideal negatif. Setelah nilai solusi ideal negatif diperoleh maka langkah selanjutnya menghitung jarak alternatif dan separasi positif $\left(\mathrm{D}^{+}\right)$. Untuk mencari nilai dari separasi positif maka sebagai berikut:

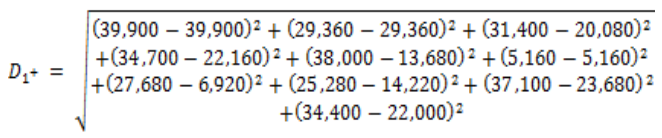

$\mathrm{D}_{1}^{+}=42.00$

$D_{1^{-}}=\sqrt{\begin{array}{c}(39,900-1,600)^{2}+(29,360-1,840)^{2}+(20,080-11,340)^{2} \\ +(22,160-5,560)^{2}+(13,680-1,520)^{2}+(5,160-5,160)^{2} \\ +(6,920-6,920)^{2}+(14,220-6,320)^{2}+(23,680-5,920)^{2} \\ +(22,000-5,520)^{2}\end{array}}$

$\mathrm{D}_{1}^{-}=58.082$

Setelah nilai separasi negative diperoleh maka tahap selanjutnya akan mencari nilai dari kedekatan relatif terhadap solusi ideal positif, dengan cara seperti contoh berikut :

$$
V_{1}=\frac{58,082}{58,082+42,000}=0,580
$$

Selanjutnya, hasil perhitungan separasi dan kedekatan relative, dirangkum pada contoh tabel 10.

Tabel 10. Matriks nilai kedekatan relatif terhadap solusi ideal positif

\begin{tabular}{cccc}
\hline \hline Kode & D+ & D- & V \\
\hline \hline A1 & 42 & 58,082 & 0,58 \\
A2 & 53,57 & 53,622 & 0,5 \\
A3 & 60,423 & 49,244 & 0,449 \\
$\ldots$. & $\ldots$. & $\ldots$. & $\ldots$. \\
$\ldots$. & $\ldots$. & $\ldots$. & $\ldots$. \\
A14 & 22,017 & 76,264 & 0,776 \\
A15 & 57,398 & 41,574 & 0,42 \\
\hline \hline
\end{tabular}

Ase Suryana, Erwin Yulianto, Khrisna Dea Pratama 
Pilihan akan diurutkan berdasarkan pada nilai D+ sehingga alternatif yang memiliki jarak terpendek dengan solusi ideal positif adalah alternatif yang terbaik.

Tabel 11 menampilkan contoh hasil akhir perhitungan penentuan pegawai berprestasi.

Tabel 11. Ranking Alternatif Pegawai Berprestasi

\begin{tabular}{ccccc}
\hline \hline \multirow{2}{*}{ KODE } & \multirow{2}{*}{ NIP } & \multirow{2}{*}{ NAMA } & $\begin{array}{c}\text { EBOBOT } \\
\text { EVALUASI }\end{array}$ & URUTAN \\
\hline \hline A14 & $13.87 .66 x x$ & Pegawai-x14 & 0,776 & 1 \\
A1 & $13.88 .62 \times x$ & Pegawai-x6 & 0,58 & 2 \\
A6 & $13.89 .62 \times x$ & Pegawai-x3 & 0,507 & 3 \\
$\ldots$ & $\ldots$ & $\ldots$ & $\ldots$ & $\ldots$ \\
\hline \hline
\end{tabular}

\section{IV.3 Diagram UML}

\section{IV.3.1 Use Case Diagram}

Perancangan use case diagram pada aplikasi yang akan dikembangkan dapat dilihat pada gambar 5. Proses pengambilan keputusan menggunakan metoda SPK diterapkan pada fitur Olah bobot preferensi dan olah data penilaian.

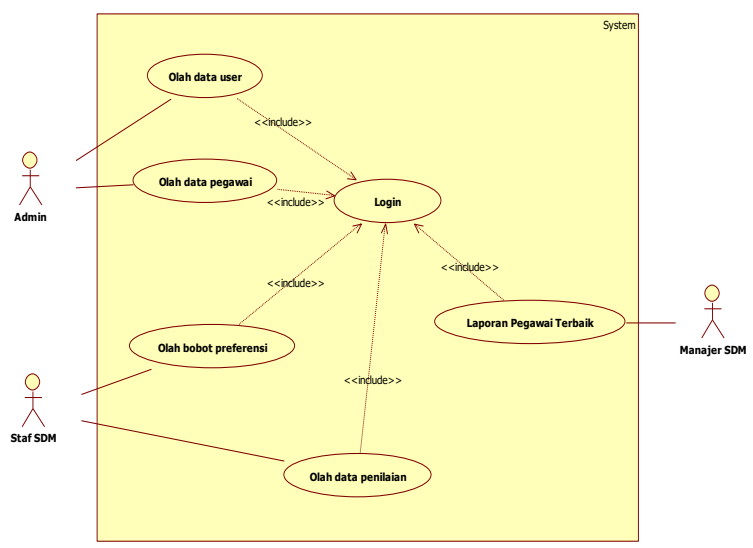

Gambar 5. Use Case Diagram

\section{IV.3.2 Class Diagram}

Class diagram ini digunakan untuk menggambarkan kumpulan dari class dan hubungannya. Class menggambarkan keadaan suatu sistem, sekaligus layanan untuk memanipulasi keadaan metode atau fungsi sehingga class memiliki tiga komponen pokok, yaitu nama, atribut, dan metode. Class diagram SPK penentuan pegawai terbaik dapat dilihat pada gambar 6 .

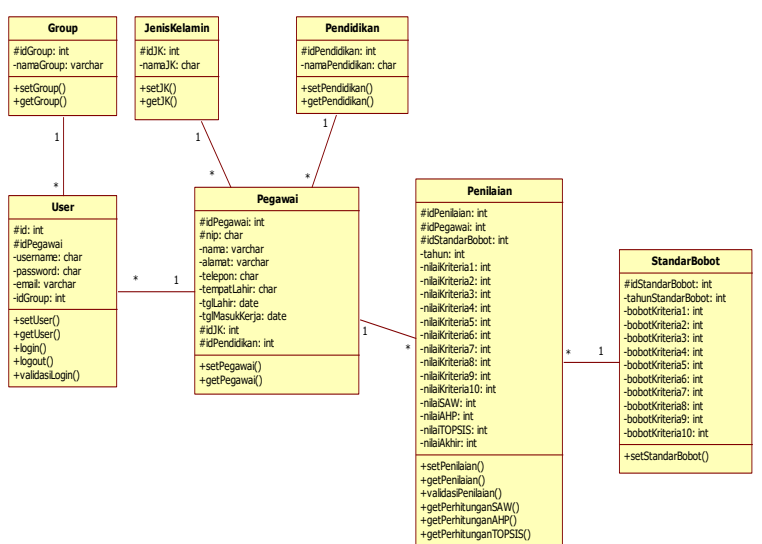

Gambar 6. Class Diagram

\section{IV.3.3 Site Map}

Desain sitemap dipakai sebagai rancangan awal dalam tahap pembangunan aplikasi untuk acuan dalam tahapan implementasi antarmuka aplikasi. Desain sitemap untuk hirarki menu dapat dilihat pada gambar 7.

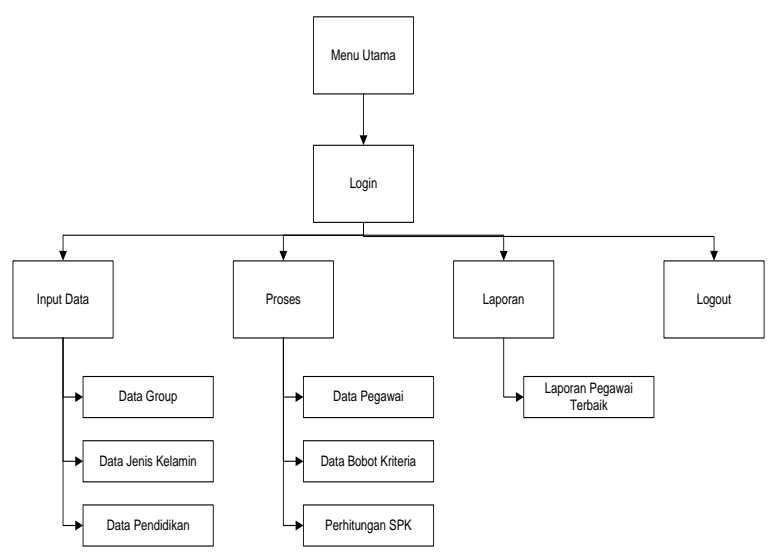

Gambar 7. Desain Sitemap

Ase Suryana, Erwin Yulianto, Khrisna Dea Pratama 


\section{IV.3.4 Perancangan Basis Data}

Perancangan tabel yang akan digunakan di dalam database Sistem Pendukung Keputusan Penentuan Pegawai Terbaik dapat dilihat pada tabel 12 sebagai berikut.

Tabel 12. Desain Tabel

\begin{tabular}{|c|c|c|}
\hline No & Nama Tabel & Fields \\
\hline 1. & TGrup & IdGroup (PK), namaGroup \\
\hline 2. & TPendidikan & $\begin{array}{l}\text { IdPendidikan (PK) } \\
\text { namaPendidikan }\end{array}$ \\
\hline 3. & TPegawai & $\begin{array}{l}\text { IdPegawai (PK), NIP, Nama, JK, } \\
\text { Alamat, Telepon, TempatLahir, } \\
\text { TglLahir, TglMasukKerja, } \\
\text { idPendidikan }\end{array}$ \\
\hline 4. & TBobot & $\begin{array}{l}\text { idBobot (PK), tahunBobot, } \\
\text { bobotKriteria1, bobotKriteria2, ..., } \\
\text { bobotKriteria10 }\end{array}$ \\
\hline 5. & TPenilaian & $\begin{array}{l}\text { idPenilaian }(\mathbf{P K}), \text { idPegawai }(\mathrm{FK}), \\
\text { idBobot }(F K) \text {, tahunPenilaian, } \\
\text { nilaiKriteria1, nilaiKriteria2, ..., } \\
\text { nilaiKriteria10, nilaiSAW, } \\
\text { nilaiAHP, nilaiTOPSIS, nilaiAkhir }\end{array}$ \\
\hline
\end{tabular}

\section{KESIMPULAN DAN SARAN}

\section{V.1 Kesimpulan}

Penelitian ini menghasilkan kesimpulan sebagai berikut:

1. Sistem pendukung keputusan dapat merekomendasikan pegawai terbaik di bank bjb berdasarkan kriteria yang telah ditetapkan yaitu nilai kinerja individu, nilai kinerja unit kerja, kehadiran, perilaku, pencapaian target kerja, masa kerja, pendidikan, nilai makalah, presentasi dan hasil wawancara dengan menggunakan metode SAW, AHP dan TOPSIS

2. Keuntungan / manfaat menggunakan ketiga metode ini sekaligus, antara lain dapat membantu menentukan keputusan pemilihan pegawai terbaik dengan tepat dan meminimalisasi subjektivitas. Selain itu keputusan yang diambil sekarang bisa menjadi acuan untuk menentukan keputusan yang akan diambil di masa yang akan datang untuk menghasilkan objektifitas yang lebih baik.

3. Uji coba yang dilakukan dengan memasukkan sample pegawai sebanyak lima belas orang dengan menggunakan perhitungan metode SAW, AHP dan TOPSIS dapat memberikan rekomendasi pegawai terbaik berdasarkan ranking / peringkat.

\section{V.2 Saran}

Saran yang diharapkan untuk menjadi bahan evaluasi untuk penelitian selanjutnya yaitu penambahan kriteria penilaian. Dengan semakin banyak kriteria yang diperhitungkan dalam metode SAW, AHP, dan TOPSIS, maka hasil yang diharapkan dapat semakin konsisten, akurat dan dapat dipercaya.

\section{Daftar Pustaka}

C.L.Hwang, K. Yoon. 1981. Multiple Attributes Decision Making Methods \& Applications. Springer : Berlin Heidelberg.

Daihani, Dadan Umar. 2001. Sistem Pendukung Keputusan. Penerbit Elex Media Komputindo, Jakarta

Kusumadewi, Sri., Hartati, S., Harjoko A., dan Wardoyo R. 2006, Fuzzy Multi Atribute Decision Making (FUZZY MADM). Yogyakarta: Penerbit Graha Ilmu

Kusrini. 2007. Konsep dan Aplikasi Sistem Pendukung Keputusan. Yogyakarta: Andi

Sinaga, Johannes. 2009. Penerapan Analytical Hierarchy Process (AHP) dalam Pemilihan Perusahaan Badan Usaha Milik Negara (BUMN) Sebagai Tempat Kerja Mahasiswa Universitas Sumatera Utara. Universitas Sumatera Utara

Turban, Aronson, dan Liang. 2005. Decision Support System and Intelligent Systems (Sistem Pendukung Keputusan dan Sistem Cerdas) Jilid I Edisi 7. Yogyakarta: Andi. 